\title{
Erratum
}

In Eur. Surg. Volume 34, Issue No. 4, pp. 248-249, Table 1 and 2 were missing. The correct abstract is shown below. The publishers do apologize for this error.

\section{Minimally Invasive Surgery for Oesophageal Cancer} R. Roka', St. Kriwanek' and S. Roka ${ }^{2}$ ('1st Department of Surgery, Krankenanstalt Rudolfstiftung, ${ }^{2}$ Division of General Surgery, Department of Surgery, University Vienna)

Background: Oesophagectomy is associated with significant risk of operative morbidity and mortality. To minimise invasiveness, thoracoscopic and video-assisted oesophagectomy or mediastinal dissection are performed and described by some authors. Its role is still controversial.

Methods: In this paper we describe our experience in four patients with squammous cell cancer of the oesophagus, that were treated by thoracoscopic oesophagectomy. Furthermore we discuss the expertise published in the literature.

Results: Personal Experience: Four male patients with squammous cell cancer of the upper and middle part of the oesophagus underwent thoracoscopic esophagectomy. Four or five trocars were used. After dissection of the azygos vein, the tumour and neighbouring lymph nodes were mobilised. Radical lymphadenectomy was time consuming and technically difficult. The median time for thoracoscopy was 150 minutes. There were no complications in respect to the endoscopic method, but all patients needed prolonged treatment in an intensive care unit due to pulmonary complications. One patient died two months after sur- gery from necrotising pancreatitis. Two patients had tumour recurrence 10 and 11 months after surgery.

Expertise in the literature: Thoracoscopic and video-assisted methods published in the literature are summarised in Table 1. Table 2 shows the results of the three largest series.

Conclusions: Thoracoscopic esophagectomy provides a safer and oncologically more complete resection, compared to the "blunt dissection". Therefore this technique appears beneficial mainly for oesophageal cancer in the upper thoracic level, if thoracotomy should be avoided, and for staging in special cases. Radical resections, as demanded in the literature, could be realised only by a small number of surgeons and in limited groups of patients. Noteworthy was the short time to tumour recurrence in some series $(5,6)$.

\section{References}

(1) Akaishi T, Kaneda I, Higuchi N, Kuriya Y, Kuramoto J, Toyoda T, Wakabayashi A: Thoracoscopic en bloc total esophagectony with radical mediastinal lymphadenectomy. J Thorac Cardiovasc Surg 1996:112:1533-1540.

(2) Buess G, Kaiser J, Manncke K. Walter DH. Bessell JR, Becker HD: Endoscopic microsurgical dissection of the esophagus (EMDE). Int Surs 1997;82:109112

(3) Coral RP, Constant Neto M, Silva IS, Barros S, da Silva LC, Lau AT, DeBem AE: The influence of the transposed stomach through the posterior mediastinum on the respiratory forced expiratory yolume and forced vital capacily in patients with resected esophageal cancer. Dis Esophagus 1998;11:48-50.

(4) Jagot P, Saluvanet A, Berthoux L, Belghiti $J$ : Laparoscopic mobilization of the stomach for oesophageal replacement. Br J Surg 1996:83:540-542.

(5) Kawahata K. Marekawa T, Okabayashi K. Hideshima T, Shiraishi T, Yoshinaga Y, Shirakusa T: Video-assisted thoracoscopic esophagectomy for esophageal cancer. Surg Endosc 1999:13:218-223.

(6) Law S. Fok M. Clu KM. Wong J: Thoracoscopic esophagectomy for esophat gead cancer. Surgery 1997:122:8-14.

(7) Watson DI. Davies N. Jamieson GG: Totally endoscopic Ivor Lewis esophagectomy. Surg Endose 1999; 13:293-297

Table 1. Endoscopic and thoracoscopic methods for the treatment of oesophageal cancer:

\begin{tabular}{|l|l|l|}
\hline Method & Author & Reference \\
\hline Endoscopic microsurgical dissection of the esophagus & Buess et al. & $(2)$ \\
\hline Videoassisted transhiatal esophagectomy & Coral et al. & (3) \\
\hline Laparoscopic mobilization of the stomach & Jagot et al. & (4) \\
\hline Thoracoscopic (video-assisted, en-bloc) esophagectomy & Lawet et al., Kawahara et al., Akaishi et al. & (6) (5) (1) \\
\hline Totally Ivor-Lewis esophagectomy & Watson & (7) \\
\hline
\end{tabular}

Table 2. Minimally invasive surgery for oesophageal cancer: Review of literature.

\begin{tabular}{|l|l|l|l|l|l|}
\hline Author & Method & $\mathbf{n}$ & $\begin{array}{l}\text { Operating } \\
\text { time }\end{array}$ & Complications & Follow-up \\
\hline Law (6) & $\begin{array}{l}\text { Radical thoracoscopic } \\
\text { esophagectomy }\end{array}$ & 22 & 110 minutes & - & $\begin{array}{l}6 \text { local recurrences } \\
(9-15 \text { months })\end{array}$ \\
\hline Kawahara (5) & $\begin{array}{l}\text { Radical thoracoscopic video- } \\
\text { assisted esophagectomy }\end{array}$ & 23 & 111 minutes & $\begin{array}{l}\text { Recurr. Nerve palsy 5, } \\
\text { tracheal injury 1, thoracic } \\
\text { duct fistula 1 }\end{array}$ & $\begin{array}{l}5 \text { local recurrences } \\
(2-10 \text { months) }\end{array}$ \\
\hline Akaishi (1) & $\begin{array}{l}\text { Radical thoracoscopic en- } \\
\text { bloc total esophagectomy }\end{array}$ & 39 & 200 minutes & $\begin{array}{l}\text { Recurr. Nerve palsy } 7, \\
\text { pulmonary complications } 9\end{array}$ & 0 \\
\hline
\end{tabular}

